\title{
СПЕЦИФИЧНОСТИ ВО ПРИМЕНАТА НА НАСТАВНИТЕ СРЕДСТВА И СПЕЦИФИЧНИ ПОМАГАЛА ВО НАСТАВАТА ЗА УЧЕНИЦИТЕ СО МОТОРНИ НАРУШУВАҢА
}

\section{Peзиме}

Иако за училиштето размислуваме како за статична институција, сепак образованието го доживува својот подем и се менува, вклучувајки го и образованието на деца со попреченост.

Со донесуване на Законот за образование во 2019 година, во Р Македонија започнува процесот на потполна инклузија, што значи дека основното образование е институциионално, кадровски и содржински организирано на начин кој поддржува вклучуване на сите ученици во редовното основно образование.

По предлог на Бирото за развој на образованието, министерот за образование и наука утврди НОРМАТИВИ И СТАН,ДАРДИ за простор, опрема и наставни средства за основно училиште во Република Северна Македонија. Иако за ученицичте со ПОП е наведено дека ќе се користат спецзијализирани наставни средства и учебни помагала како и асистивна технологија во зависност од индивидуалните можности, способности и потреби на ученикот со попреченост, сепак опфатеноста во програмските документи е општа.

Оттука произлезе потребата од пишуване на овој труд, да се допрецизираат специфичностите во користенето на наставните средства и помагала во инклузивна училница. т.е. на кој начин наставните средства и учебни помагала кои се предвидени за учениците со типичен развој ке станат специиализирани, $u$ кои спецьиични наставни средства, посебни учебни помагала и асистивна технологија се потребни за ученикот со моторни нарушувана.

Клучни зборови: основно образование, учениции со моторни нарущуваньа, наставни средства, помагала во наставата

„Образованието во дваесет и првиот век ќе доживее трансформација која поаѓа од индивидуата и нејзините потреби. Во овој факт треба да се види новиот дух на образованието."

Миле Ненадиќ 


\section{Вовед}

Во мислите вратете се 75 или 100 години наназад. Сега одете брзо напред, до денес. Во тој период од минатото до денес се случиле многу промени во развојот на човештвото. Мислиме на земјоделството пред 100 години и денес. Мисдиме на медицинската пракса пред 100 години и денес. Замислете каков бил превозот пред 100 години, а каков е денес!? Размислете за промените во 20 век во областа на инженерството, на модата и во комуникацијата. Трансформацијата е зачудувачка, нели? Додека повеќето од нас чувствуваат ностадгија за „старите добри времиња“, ретко кој ќе одлучи да биде лекуван од поранешните лекари, да користи стари комуникациски системи или да ја преферира поранешната мода (носење селска носија или староградска облека).

Развојот на технологијата и науката, осовременувањето на општественото уредување, меѓу другото имаше големо вдијание и врз односот и третманот кон дицата со попреченост. Во последните 70 години измените во терминологијата, гледиштата, ставовите предизвикаа радикални промени во образованието на деца со попреченост, вклучувајќи ги и децата со моторни нарушувања и телесна инвалидност, потенцирајќи нови теории и практики за тоа како најдобро можат да се едуцираат овие деца (Fox, 2003).

Кога станува збор за инклузијата како веќе неминовен дел од современата образовна средина, постои значаен збир од размисли во однос на нејзиното суштинско значење - најпрво како поим, а потоа и како составна практика на образовниот процес и на целокупниот општествен систем. Затоа, „овозможувањето на квалитетно образование во инклузивна средина претставува најголемиот предизвик во современото образование, каде што клучната идеја поврзана со инклузијата и социјалната правда е еднаквоста - како морален принцип кој произлегува од значењето на тој збор - праведност" (Bouillet D, Kudek-Miroshevich J., 2015). Почетоците на идејата за инклузијата датираат од 1994 г., кога била промовирана во Изјавата и Акциската рамка од Саламанка и се однесува на формата на школување која би требало да обезбеди поддршка на децата со посебни образовни потреби (ПОП) вклучени во редовните училишта за да овозможи ефикасно образование (Диздаревиќ А и сор., 2017).

Уште пред завршетокот на минатиот век, започнало да преовладува мислењето дека специјалното образование е повеќе проблем отколку решение при овозможувањето на соодветно образование за учениците со попречености (Uditsky В., 2003), што и го условило прифаќањето на системот на целосната инклузија. Еден од најубедливите аргументи поставени во нејзина полза претставува ставот дека „доста ученици во специјалното образование се неосновано класифицирани и веројатно се подложни на инфериорни услуги, а во некои случаи и на навредливо етикетирање и стереотипи“ (Uditsky В., 2003, Јордановска Ж, Ценевска 3.О., 2008). Повеќе од очигледно е дека концептот на специјалното образование „претставува 
пречка за развојот на инкдузијата, затоа што го ослободува останатиот дел од образовниот систем од преземање одговорност за учењето на сите деца“ (Rouse M., 2008). Наставниците имаат професионална одговорност и обврска да следат чекор со промените во образованието (Rose R \& Howley M, 2007). Од овие причини, целосната инклузија, како најоправдана практика, подразбира „трансформација на училиштата за да ги згрижат сите деца“, во смисла на просторни, функционални и програмски адаптации - кои заземаат централно место во инклузивниот процес (Mitchel D., 2015).

Со донесување на Законот за образование во 2019 година, во РС Македонија започнува процесот на потполна или т.н. целосна инклузија. Но, денешните наставници сѐ уште се соочуваат со основниот предизвик на училницата - како да се постигне ефикасно учење за сите ученици. Важно е да се запомни дека дури и најискусниот наставник нема да може да понуди „готов“ одговор на сите предизвици со кои ќе се соочи при изведувањето на наставата. Добрите наставници постојано ја ревидираат својата работа и го оценуваат начинот на којшто реагираат учениците на нивниот пристап. Врз основа на таквото ревидирање, можно е да се идентификуваат специфичните потреби на учениците и да се направат приспособувања со кои ќе се обезбеди нивното учество во наставата.

Успешната реализација на деветгодишното задолжително основно образование зависи од квадитетно изработените наставни програми, доброедуцираниот наставен кадар и соодветните просторни услови, вклучувајќи ги тука и опремата и наставните средства.

\section{Ресурси за учење}

Јан Амос Коменски во неговата книга „Голема дидактика“, објавена во 1630 година, напишал дека за да научат, учениците мораат да „видат, слушнат, допрат или да вкусат“. Сетилните искуства ја создаваат основата на најголемиот дел на интелектуалната активност.

Вилјам Гласер (William Glasser) тврдел дека „ние учиме...“

$\Rightarrow 10 \%$ од она што го читаме;

$\Rightarrow 20 \%$ од она што го слушаме;

$\Rightarrow 30 \%$ од она што го гледаме;

$\Rightarrow 50$ \% од она што го гледаме и слушаме;

$\Rightarrow 70 \%$ од она што го дискутираме;

$\Rightarrow 80 \%$ од она што го правиме (од нашето искуство);

$\Rightarrow 95$ \% од она што го учиме од другите (во Houff SG, 2010).

Што се ресурси за учење? Тоа се алатки што го овозможуваат, олеснуваат или го поддржуваат процесот на учење кај учениците, кои се движат од говорни карактеристики, вокален квалитет, изрази на дице и гестикулации, па сѐ до материјади и опрема. Исто така ги вклучуваат и „наставните помагала“ како пенкало, хартија, табла, маркер, креда, проек- 
тор, компјутер, телевизор, електронска табла и сл. Ресурсите за учење се корисни и за учениците и за наставниците.

Кога станува збор за учениците, ресурсите можат да ги зголемат можностите за учење, го подобруваат разбирањето на материјата, будат интерес, ја зголемуваат мотивацијата и придонесуваат за позитивни ставови кон одредени предмети и кон учењето воопшто.

Што се однесува до наставниците, ресурсите за учење можат да ја подобрат, прошират или да ја збогатат наставата и да им помогнат во воспоставувањето и одржувањето на амбиентот во којшто се одвива учењето (Корен С, 2013).

За да бидат ефикасни, ресурсите за учење не само што мора да се на иста линија со целите туку мора да се соодветни за учениците во поглед на нивната возраст, претходни искуства и знаење, како и ниво на развој и (ограничени) физички можности. На учениците кои никогаш не користеле одреден ресурс ќе им биде потребно подолго време да се навикнат на тој ресурс и соодветно да го искористат. Конечно, при ограничени физички можности, како слаб вид, слаб слух, дислексија, далтонизам и други недостатоци, одредени ресурси може да бидат сосема несоодветни и неефикасни.

Врз основа на член 23 став 1, алинеја 3 и став 3 од Законот за основно образование („Службен весник на Република Северна Македонија“ бр. 161 од 5.8.2019 година) министерот за образование и наука утврди НОРМАТИВИ И СТАНДАРДИ за простор, опрема и наставни средства за основно училиште во Република Северна Македонија, по предлог на Бирото за развој на образованието, со Решение бр.18-6466/2 од 10.7.2020 година. Документот е изработен со цел да ги задоводи современите стандарди и норми за простор и опрема во деветгодишното основно учидиште, а меѓу другите подрачја, опфатено е и подрачјето наставни средства и помагала. Меѓутоа, опфатеноста на наставните средства и помагада во програмските документи е општа, со што се наметнува потребата од изготвување посебен документ во кој се опфаќаат наставните средства, помагала и материјали на ниво на основни училишта во Република Северна Македонија.

Нормативите и стандардите за простор, опрема и наставни средства за деветгодишното основно училиште во Република Северна Македонија се однесуваат и на инкдузивното образование, согласно чден 11 од Законот за основно образование и истите се разумно приспособени според индивидуалните потреби на ученикот. Но, дади ова е навистина така ќе погледнеме во продолжение каде ќе ги издвоиме деловите кои се однесуваат на наставните средства и помагала за учениците со попреченост од првиот, вториот и третиот развоен период.

- За работа со учениците со попреченост ќе се користат играчките, предметите и материјалите кои се предвидени за учениците со типичен развој од ПРВИОТ развоен период, како и специфични наставни средства и асистивна технологија, во зависност од ин- 
дивидуалните можности, способности и потреби на ученикот со попреченост.

- За настава со учениците со попреченост ќе се користат специјализирани наставни средства и учебни помагала кои се предвидени за учениците со типичен развој од ВТОРИОТ развоен период, како и специфични наставни средства, посебни учебни помагала и асистивна технологија во зависност од индивидуалните можности, способности и потреби на ученикот со попреченост.

- За наставата со учениците со попреченост ќе се користат специјализирани наставни средства и учебни помагала кои се предвидени за учениците со типичен развој од ТРЕТИОТ развоен период, како и специфични наставни средства, посебни учебни помагала и асистивна технологија во зависност од индивидуалните можности, способности и потреби на ученикот со попреченост (НОРМАТИВИ И СТАНДАРДИ за простор, опрема и наставни средства за основно училиште во Република Северна Македонија, 2020).

Генералната воопштеност на документот беше основата од која произлезе потребата за пишување на овој труд, да се допрецизираат специфичностите во користењето на наставните средства и помагала во инклузивна училница. т.е. на кој начин наставните средства и учебни помагала кои се предвидени за учениците со типичен развој ќе станат специјализирани, и кои специфични наставни средства, посебни учебни помагала и асистивна технологија се потребни за ученикот со моторни нарушувања.

\section{Кдасификација на наставните средства}

Пред да се пристапи кон класификација на наставните средства цениме дека е значајно поимното одредување на овој термин. Соодветното терминолошко поимање е предуслов и на соодветниот однос на наставните средства и нивната примена во наставата. Наставните средства се јавуваат како посредници во наставниот процес при пренесување информации заради стекнување знаење. Во тоа посредување наставните средства се наоѓаат помеѓу оние кои се во комуникациски однос, оној кој дава и оној кој прима информација: наставник - ученик или ученик - ученик. Бидејќи наставните средства се наоѓаат во улога на посредник помеѓу оние кои се во интеракција, уште се нарекуваат дидактички медиуми (медиум - оној кој се наоѓа во средината - посредник во комуникацијата). Но сите технички средства не се дидактички медиуми. Училишната табла, микроскопот, телевизорот, компјутерот, сами по себе не се медиуми; тие тоа стануваат тогаш кога почнуваат да остваруваат дидактичка функција, а тоа значи кога во еден планиран и систематски организиран процес служат да се остварат целите на поучување и учење. 
Постојат бројни обиди за кдасификација на наставните средства. Наједноставната поделба на материјалите на кои учениците стекнуваат знаења е поделбата на две групи: едната група ја сочинува сето она што се наоѓa во нашето опкружување, а не е направено за потребите на наставата (природни); другата група ја сочинуваат наставните медиуми кои се изработени наменски конкретно за успешна реализација на наставниот процес (вештачки).

Кога станува збор за класификација на наставните средства, најчеста е поделбата по критериумот на сетилата кои учествуваат во користењето на медиумите. Во таа смисла медиумите се делат на визуелни, аудитивни и аудиовизуелни. Посебна група се текстуалните медиуми, сметачите и јазичните лаборатории, симулатори и тренажери.

Без оглед на тоа кои ресурси за учење ќе ги одбере или ќе ги создаде наставникот, сепак негова одговорност е да ги „оживее“ заедно со своите ученици. Треба да запомниме дека ресурсите за учење - дури и најинтерактивните меѓу нив - претставуваат само алатки, наставникот е тој што мора да ги користи добро и мудро. Не постои универзадно наставно средство со чија примена може успешно де се заменат останатите наставни средства - секое има своја дидактичка вредност. Се разбира, едно дидактичко средство не ја исклучува употребата на друго, но сепак мора да се води сметка дека средствата кои се користат во текот на еден час треба меѓусебно да се дополнуваат и да придонесуваат учениците да се здобијат со што поцелосни сознанија во текот на часот. Наставникот треба да ги користи оние дидактички средства со чија помош ќе може на учениците најочигдедно, најдобро и најлесно да им ја објасни содржината на наставната единица која се обработува.

\section{Специфичности во примената на наставните средства во наставата за учениците со моторни нарушувања}

Неретко природата и карактеристиките на моторните нарушувања и телесна инвадидност ги оневозможуваат децата нормално да стекнуваат искуства, да ја запознаваат средината, да се движат и истражуваат. Состојбата станува уште потешка заради честото одвојување од природната средина и родителите заради болнички третмани или рехабилитација, што е причина за недоволна стимулација, при што детето станува инертно, немотивирано, незаинтересирано. Сето тоа води до заостанување во голем број на сознајни функции, но најчесто е нарушувањето или слабиот развој на перцептивните функции, особено способноста за детерминирање одредени квадитети на предметите, одредување причинско-последична поврзаност. Оттука произлегува потребата од примена на посебно одбрани, специфични, приспособени наставни средства и ресусрси. 
Аудитивни наставни средства (Аудиомедиуми)

Преку аудитивни наставни средства се упатуваат сите оние пораки кои се примаат со сетидото за слух. Аудитивните наставни средства имаат широка примена во работата со учениците со моторни нарушувања. Тие непосредно ги приближуваат звуците, кои поголемиот број од овие ученици, поради имобилноста, хоспитализацијата или домското сместување, не им се познати. Овие средства се од големо значење за развој на аудитивната перцепција, слушната дискриминација, аудитивното внимание и ритамот. Сепак, при нивната примена треба да се почитуваат одредени правила. Кај децата кај кои постои нарушување во аудитивната перцепција, а наставните средства имаат задача да додоват некое случување во природата, ова средство може да се користи само со почитување на правидото: едно слушање - еден звук. Треба да бидеме внимателни и при пуштањето звуци на учениците кај кои се дијагностицирани епилептични напади, бидејќ́ ненадејните и силни звуци можат да ги испровоцираат.

Визуелни наставни средства (Визуелни медиуми)

Најголем број на впечатоци од реалноста примаме со сетилото за вид. Оттука, во наставата, визуелните медиуми имаат поголемо значење отколку аудитивните. Визуелните наставни средства, со оглед на димензијата, можат да бидат: дводимензионални и тридимензионални, а со оглед на дидактичката намена можат да бидат: статички и динамички. Визуелните медиуми најчесто ги надополнуваат другите медиуми, иако можат да се користат и самостојно. Употребата на овие медиуми се темеди на фактот што тие се помалку апстрактни од печатените материјали и од човечките ресурси.

Кај учениците со моторни нарушувања, кај кои е присутно и нарушување на визуелната перцепција, при примената на визуелните наставни медиуми, потребно е дводимензионалните наставни медиуми да бидат зголемени, со намален или приспособен број детали, со јасен контраст помеѓу сликите и заднината, со сидни бои и да бидат што пореадни. Исто така, треба да се внимава, доколку на часот се користат повеќе наставни средства, тие треба да бидат така распоредени што најнапред ќе се користи само едно, па потоа истото ќе се тргне, па ќе се прикаже второто и сл. за да се избегне одвлекување на вниманието на учениците. За овие ученици важи и правилото брзо менување на активностите и комбинирање на наставните ресурси од раздични групи во текот на часот. Проблемите во краткорочното и долгорочното помнење исто така бараат намален број детали, за да остане доволно време за повторување на содржината, и така да им се помогне на учениците да го запомнат градивото.

Тродимензионалните визуелни наставни средства (модели, предмети од непосредната и посредна реалност) мораат да ја следат, пред сѐ состојбата на визуелната перцепција, но и состојбата на моториката на учени- 
кот со моторни нарушувања. Покрај учеството на визуелната перцепција од огромна важност е и тактидната перцепција, т.е. можноста да се допре, држи и манипулира со нив. Затоа предметите и моделите кои се користат во работата со учениците со моторни нарушувања, треба да се приспособат во големината, за да се овозможи самостојна работа.

Кога се користат тродимензионалните визуелни наставни средства, треба да се води сметка за тоа да бидат безбедни за користење, т.е. дека нема да предизвикаат повреда кај ученикот или влошување на здравствената состојба (ова е важно за сите ученици, но од исклучителна важност е за учениците болни од дијабетес, хемофилија, бронхијална астма или друг вид алергија).

\section{Текстуални наставни средства (Печатени материјали)}

Во некои класификации на наставните средства, печатените материјали се означуваат како подгрупа на визуелните наставни средства. Овде пред сѐ спаѓаат учебниците, а потоа прирачниците, програмираните текстови, колумни, зборници итн. Учебниците се примарни ресурси за учење, додека останатите материјали се сметаат за секундарни ресурси за учење. Со цел печатените материјали да ја остварат својата наставна функција, треба да бидат дидактички обликувани. Текстот треба да биде логички систематизиран, поделен на тематски целини и единици, разбирлив за возраста и, се разбира, логично поврзан со знаењето со кое ученикот веќе располага, да е илустриран со цртежи, да има прашања и задачи за вежбање.

Примената на печатените материјали кај учениците со моторни нарушувања бара бројни приспособувања. На кој начин ќе бидат приспособени овие материјали, зависи од возраста на учениците, од нивните лексички способност, но и од потребните способности за читање, а тоа се визуелната перцепција, просторната ориентација, помнењето и вниманието. Покрај наведеното, како ќе се приспособат текстуалните материјали, зависи и од манипулативните способности на учениците.

Должината на текстот и задачите мораат да го следат нивото на развиеност на лексичките способности на ученикот за даденото писмо и дадената возраст. Со оглед на тоа што во специјалната едукација и рехабилитација на дицата со моторни нарушувања првенствено зборуваме за способности, а помалку за возраст, тогаш и овде треба да се направат одредени приспособувања. Сосем поинаква должина на текст во работните дистови ќе добијат учениците кои го имаат совладано читањето, во однос на учениците кои читаат буква по буква и тешко ги поврзуваат буквите во слогови а слоговите во збор и сл.

За учениците кои имаат проблем со просторната ориентација и следење на редот, а состојбата на моторните функции на горните екстремитети е таква, што ученикот не може со прст да го подвлекува редот, примената на текстуадните наставни средства бара активна улога на наставникот. 
Наставникот може да ги покрива редовите кои, ученикот во тој момент не треба да ги чита, давајќи му можност да го гледа редот, кој треба да се прочита. Адаптацијата може да се изврши и со помош на посебни дистови на кои е напишана по една реченица, односно еден ред, кој ученикот треба да го прочита. Читањето се врши со менување на засебните листови. Наставникот може да го адаптира текстуалното наставно средство со зголемување на текстот, зголемување на видливоста на буквите (боја, задебелување), подвлекување на важните делови од текстот и сл. (Илић-Стошовић A, 2011).

Присуството на спастицитет, хореатични и атетоидни движења на горните екстремитети, и/или глава и врат, значително ја отежнуваат примената на текстуалните наставни средства, а првенствено самиот процес на описменување. За да може ученикот со неволни движења да користи текстуални наставни средства, тие треба да бидат изработени од тврд картон. Доколку ученикот има и зголемена саливација (дигавењето се среќава кај учениците со церебрална парализа, мускулна дистрофија, повреда на глава) таквото наставно средство мора да биде пластифицирано, за полесно да се брише и подолго да се користи.

Аудиовизуелни наставни средства (Аудиовизуелни медиуми)

Самиот наслов зборува дека овде се работи за средства за кои е потребно да се користат две сетила: вид и слух. Аудиовизуелните медиуми се значајни и кога материјалните предмети или природното опкружување не се достапни. Камерата може да сними места што најголемиот број луѓе не можат да ги видат или да ги посетат (на пример, морските длабочини, културно-историски места), да им помогнат на учениците да разберат одредени процеси што не се видливи или препознатливи затоа што се пребрзи, пребавни или премали, забавување на настаните што се одвиваат брзо или да забрзување на настаните што се одвиваат во долги временски периоди (со користење временско забрзување на фотографијата може да се види растењето на растение). Современи аудиовизуелни медиуми се: наставниот фили, образовната емисија и ДВД.

Меѓутоа, користењето на аудиовизуелни медиуми во инклузивната училница не е секогаш лесно. При нивната примена, треба да се почитуваат сите правила што се однесуваат на користењето на визуелните и аудитивните медиуми. Поточно, должината на филмот иди некој друг аудиовизуелен приказ мора да биде приспособен на состојбата за помнење и внимание на учениците со моторни нарушувања. Содржината, прекините во емитувањето, фреквенцијата на објаснувањата, кои се неопходни за да се разбере содржината на аудиовизуелниот приказ, првенствено се условени од состојбата на визуелните и аудитивните способности на учениците, но и од состојбата за внимание и помнење, присуството на епидептични напади, степенот на заморливост на ученикот, нивото на оперативност на мислењето и сл. 


\section{Специфични помагала и опрема во наставата за учениците со моторни нарушувања}

За учениците со моторни нарушувања потребни се специфични помагала кои ќе овозможат непречено одвивање на воспитно-образовниот процес.

Првата и најзначајна работа за активно учество на часот и поттикнување на примената на рацете е правилното позиционирање на ученикот. Позиционирањето на ученикот може да го вклучи целото тело или само еден дел, на пример, рака. Предноста на добро позиционирање е тоа што ги олеснува движењата преку тоа што телото не мора да работи против гравитацијата. Олеснувањето на движењето, исто така значи дека детето мора да користи помалку свесна енергија за да ја одржи својата позиција. Доброто позиционирање значи оптимизирање на симетријата и стабилноста (Fox, 2003).

Симетријата значи одржување на двете страни на телото рамномерно - телото да биде во средна иинија. За многу деца со физички тешкотии постои тенденција телото да заземе неправилна положба, што може да се види кога телото е искривено кон лево или десно или пак се лизга надолу низ столчето. Ваквите положби не само што предизвикуваат долготрајни проблеми, туку исто така значат дека детето не е во најдобра положба за учење и комуникација (Рашиќ-Цаневска, Чичевска-Јованова, 2021).

Стабилност значи способност телото да се задржи во саканата положба. Колку повеќе може да се стабилизира телото, толку помалку напор треба да вдожи детето во одржувањето на положбата. Клучен аспект за одржување стабилност е контролата на главата. За детето да може активно да учи и следи настава, треба да може да ја задржи главата исправена. Без ова тоа не може да се фокусира на својата работа, не може да чита или да ги следи насоките од наставникот. Главата треба да биде исправена, во средна динија, можно малку свиткана напред (Fox, 2003). Правилното позиционирање на детето е можно само со обезбедување неопходна поддршка / опрема (сл. 1).

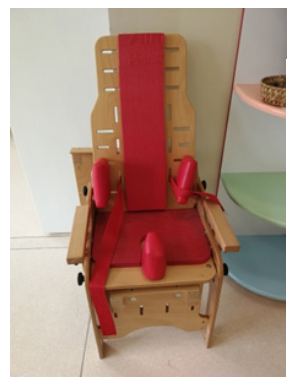

С̆. 1.

Стодче за позиционирање

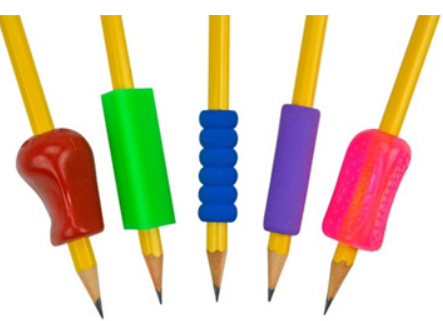

Сл. 2.

Навлаки за моливи

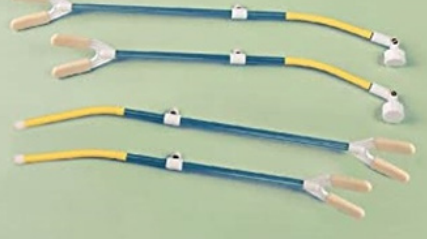

Сл. 3.

Навлаки за пишување со уста 
Работната маса на која се сместуваат учениците со моторни нарушувања треба да има поголеми димензии од обичните клупи, што ќе им овозможи полесна организација на работниот простор, со што ќе се спречи ненамерно туркање на предметите. Подлогата треба да биде посебно подготвена бидејќи голем дел од учениците не се во состојба додека пишуваат со едната рака (доминантната) со другата да го придржуваат материјалот, па затоа подлогата треба да биде леплива за да спречува лизгање.

Успехот во пишувањето ќе зависи и од приборот кој се користи во пишувањето. Постојат раздичи облици на моливи: округли, триаголни, шестоаголни и сл., но користењето на триаголен облик за 300 \% го продолжува ефективното време на пишување. Моливите и другиот прибор за пишување можат да бидат со раздични димензии (дебелина), како оптимална се наведува дебелината од 7,15 мм. Во случаи кога го немаме оптималниот обем на моливот или за ученици со недоволно диференцирана фина моторика се применуваат раздични навлаки за приборот, кои ќе овозможат зголемување на обемот (сл. 2). Ефективното пишување и заморливоста зависат и од висината на држење на приборот, а како оптимална висина се одредува 15 - 37 мм (Стошљевиќ и сор., 1990).

Во случаи на тешко моторно нарушување или отсуство на горните екстремитети еден од начините кој се применува е пишување со уста, кој е најпогоен облик по пишувањето со раце. Моливот или приборот се поставуваат на продолжеток, кој на едниот крај има навлака која се поставува во уста и се држи загризувајќи ја со забите (сл. 3). Навлаката треба да се одржува чиста, а кога ќе дојде до нејзино деформирање или оштетување да се замени, за да не дојде до оштетување на забите и непцата. Должината на продолжетокот за пишување треба да биде 16 - 18 цм., доколку е пократка ќе предизвикува заморување на очите и проблеми со видот, спротивно кога е подолга предизвикуваа тешкотии во контрола на процесот на пишување и заморување на вратот. Продолжетокот може да се користи и за работа на тастатура или користење на асистивна технологија.

Пишувањето со чело/глава е редок начин на пишување кој се применува кај ученици со квадриплегија и тешка форма на засегнатост на целокупната моторика. Околу главата во пределот на челото на ученикот се поставува манжетна на која се монтираат раздични продолжетоци за пишување или примена на асистивна технодогија.

За учениците со моторни нарушувања, кои се движат самостојно или со помагала и имаат проблеми со одржување на рамнотежата, потребно е под учидишната табла да се постави ракофат (држач) за да може ученикот непречено да ја користи таблата придржувајќи се.

Честопати се поставува прашањето: дади училиштето треба да обезбеди асистивна технологија за учениците на кои им е најпотребна. Според Актот за едукација на лицата со инвадидност, потребно е користење асистивна технодогија, и тоа за сите ученици за кои се изработуваат индивидуални образовни планови (ИОП). Актот (1988) кој се однесува на помош од 
полето на технологија за дицата со попреченост, асистивната технологија ја дефинира како „кој било предмет, парче опрема или систем на производи, без раздика дали е купен комерцијално, изменет и приспособен или пак специјално конструиран, што се користи за зголемување, одржување или подобрување на функционалните способности на дицата со попреченост". Асистивните технологии се поделени во две главни категории: „висока технологија (high tech)“ однесувајќи се на сложени софтверски програми, уреди за генерирање глас итн. и „ниска технологија (low tech)“, вкдучувајќи наједноставни помагала како бастун, помагала за облекување и сл. (Legislative History- USA in Congress assembled., 1988). Во однос на намената асистивните помагала можат да бидат поделени на (NIH, 2018): помагала за мобилност (инвалидски колички, бастуни, дубаци, протези итн.); помагала за комуникација (говорна табла, генератор на глас); помагала за олеснување на процесот на учење (читач на текст - text to speech, конвертор на усниот во писмен говор, приспособени и алтернативни вдезни уреди, гласовен калкулатор, електричен вртач на страници итн.); помагала за зголемување на функционалноста (орална телескопска ортоза); когнитивни помагала (компјутери, таблети, паметни телефони или други електрични уреди кои ќе ја подобрат меморијата, ориентацијата на корисникот).

\section{Заклучок}

Образовниот систем има за цел на ученикот да му обезбеди услови за непречено одвивање на воспитно-образовниот процес и вертикален премин. Не постојат специфично одредени правила и детерминанти за видот и начинот на користење на наставните средства, помагала и асистивна технологија во корелација со ИОП, но кога истите се соодветно вклучени и применети се зголемува веројатноста дека ученикот кој ги користи, ќе биде поефективен, подобро ќе ги искористи своите потенцијади и ќе биде успешно инклудиран. 


\section{Дитература}

Bouillet, D., Kudek-Miroshevich, J. (2015). Students with Disabilities and Challenges in Educational Practice In Prskalo I, editor. Croatian Journal of Education; 17 (2): 11-26.

Fox, M. (2003). Including children 3-11 with physical disabilities. David Fulton Publishers. Rouse M. Developing Inclusive Practice: A role for Teachers and Teacher Education? In Education in the North 2008; 6 (1): 1-20.

Houff, S.G. (2010). The classroom facilitator Special Issue Questions. United Kingdom: Rowman \& Littlefield Education.

LEGISLATIVE HISTORY. (1988). Technology-Related Assistance for Disabilities Act. In PUBLIC LAW 100-407-AUG. 19, 1988.

Mitchel, D. (2015). Inclusive Education is a Multi-Faceted Concept In Devetak I., editor. Centar for Educational Policy Studies Journal; 5 (1): 9-30.

National Institutes of Health. (2018). What are some types of assistive devices and how are they used?. [cited 2020] Available from URL: https://www.nichd. nih.gov/health/topics/rehabtech/conditioninfo/device

Uditsky, B. (2003). From Integration to Inclusion: The Canadian Experience In Slee R., editor. Is There a Desk with My Name on It?: The Politics of Integration. Abingdon: Routlege.

Диздаревиќ, А. и сор. (2017). Споредба на ставовите на наставниците за инклузивното образование во Босна и Херцеговина и во Европската Унија. Во Дефектолошка теорија и практика; 18 (1-2): 92-108.

Илић-Стошовић, Д. (2011). Теорија васпитаюь и образовать особа са моторним поремес́ајима. Београд: Факултет за специјалну едукацију и рехабилитацију-Издавачки центар (ЦИДД).

Јордановска, Ж., Ценевска, 3.О. (2008). Посебни образовни потреби: работа со ученици со посебни образовни потреби. Скопје: Алгоритам Центар.

Корен, С. (2013). Ресурси за учење. Во Настава за да се научи: референтен водич за наставници ориентирани кон резултати. Београд: Гама Дигитал Центар.

НОРМАТИВИ И СТАНДАРДИ за простор, опрема и наставни средства за основно училиште во Република Северна Македонија (2020). [цитирано 2021] Достапна на https://mon.gov.mk/stored/document/Normativi\%20 i\%20standardi\%20za\%20osnovno\%20uciliste.pdf

Рашиќ-Цаневска, О., Чичевска-Јованова, Н. (2021). Методика на работа со учениции со моторни нарушувана. Скопје: Филозофски факултет.

Службен весник на РСМ, бр. 161 од 5.8.2019 година. Закон за основно образование.

Стошљевиќ, А., Рапаиќ, Д., Николиќ, С. (1990). Соматопедиа. Београд: Научна Књига. 
